\title{
'THEY SHALL NOT DRAW NIGH' THE ACCESS OF UNBELIEVERS TO SACRED SPACE IN ISLAMIC AND JEWISH LAW
}

\author{
Ze'ev Maghen
}

\author{
BAR ILAN UNIVERSITY, TEL AVIV
}

This essay compares the Sunn̄̄ Muslim position(s) concerning the ingress of non-Muslims to the Meccan Sanctuary with the Rabbinic outlook on the entry of non-Jews into the Temple precinct. In both cases, the issue is one of purity and pollution, and the algorithms of each religion's ritual code are therefore probed in search of the underlying bases for their respective policies on the subject. The discussion will follow the legists through their intricate evaluation of what is perceived by many today to be 'minutiae' - it was certainly not seen thus by the jurists themselves. The attitudes of Shari ${ }^{\mathrm{c}}$ a and Halakha to immersion for the sake of conversion also harbor significant implications for this question, and space is devoted to elucidating the two systems' variant rationales for requiring this ceremony. Our conclusions reveal a significant difference indeed, a diametric antithesis - between Judaism's and Islam's conceptions of the cultic status of the other.

\section{Text and Context}

We begin with a complex exegetical problem. In his classic The Zāhirīs: Their Doctrine and Their History, Ignaz Goldziher digresses momentarily from a discussion of the jurist Ibn Hazm's literalism in order to praise the Sunnī scholars for their ecumenical attitude to the question of infidel impurity (najāsat al-mushrikīn). Goldziher explains how, as opposed to the 'utmost rigorism and intolerance' of the Zāhirīs and $\mathrm{Sh}^{\mathrm{c}} \mathrm{a}$ - who consign all non-Muslims to the category of intrinsically unclean and contagiously polluting objects (nawājis al-dhāt, a yān alnajāsa):

Sunnite Islam...has displayed in this point a splendid example of its perfectibility, its possibility of evolution, and also the ability to adapt its rigid formalism to the requirements of social intercourse by modifying the Koranic tenets of the impurity of unbelievers through its own interpretation, until it reached the point when it abandoned this doctrine. ${ }^{1}$

\footnotetext{
${ }^{1}$ Ignaz Goldziher, The Zāhirīs: Their Doctrine and Their History, trans. and ed. Wolfgang Behn (Leiden: E. J. Brill, 1971), 58.
} 
In a previous article, the present author has fleshed out the few sentences Goldziher devoted to this subject and delved into the significant exegetical and legal differences between the $\operatorname{Sh}^{\bar{c}} \overline{1}$, Zāhirī and Sunn̄̄ positions. ${ }^{2}$ While my conclusions on the whole supported Goldziher's assessment, there is one area in which I believe his remarks require some fine tuning, and we must attend to this before proceeding to the main subject of this paper: the access of unbelievers to Muslim and Jewish holy sites.

The evidence Goldziher marshals to bolster his claim that Sunnism 'moderated' and ultimately 'abandoned' its own (and the Qur'ān's) original outlook on the ritual status of unbelievers involves the slightly divergent rulings of the Shāfi ${ }^{c} \overline{1}$, Mālikī and Hanafì legal schools regarding the areas considered off-limits to non-Muslims. He sees a sort of anti-chronological pattern of liberalization in progressively more 'tolerant' interpretations put by these madhāhib on the revelevant scriptural clause (Qur ${ }^{\circ} \bar{n}$ 9:28), culminating with the Hanafite acceptance of the 'provisional stay' of a member of one of the Peoples of the Book even inside the borders of the harām or sanctuary at Mecca itself. He writes:

The three more liberal of the legal schools represent in their interpretations of this Koranic verse one stage each of this gradual process. Al-Shāfi ${ }^{c}{ }^{\prime}$ 's school is of the opinion that nothing can be deduced from this verse but the prohibition against unbelievers entering the holy territory in Mecca; the Mālikite school extends this prohibition to all the mosques of Mecca; according to the view of the Hanafites, believers of other faiths are not even barred from entering the holy harām territory for a provisional stay (al-Māwardī, p. 290). The latter interpretation just about abrogates the validity of the Koranic prohibition! ${ }^{3}$

Let us briefly examine the verse in question, together with some excerpts from its exegesis, in order to propose a subtle but portentous corrective to Goldziher's portrayal of the issue. Qur ${ }^{\circ} \overline{\mathrm{n}}$ 9:28 reads:

$\mathrm{O}$ believers, the idolaters are indeed unclean [innamā l-mushriküna najas]; so let them not come near the Holy Mosque after this year of theirs [is over] [ $f a-l \bar{a}$ yaqrabū l-masjida l-harāma $\left.b a^{c} d a^{c} \bar{a} m i h i m ~ h a \bar{a} h \bar{a}\right]$. If you fear poverty, God shall surely enrich you of His bounty, if He will; God is All-Knowing, AllWise. $^{4}$

2 Ze'ev Maghen, 'Strangers and Brothers: The Ritual Status of Unbelievers in Early Islamic Jurisprudence', Medieval Encounters 12/2 (2006): 248-311.

${ }^{3}$ Goldziher, Zāhirīs, 59, n. 1.

${ }^{4}$ Trans. A. J. Arberry, The Koran Interpreted (various editions), capitalization altered and additions in square brackets. Verse numbers in this article are cited according to the now generally accepted division of the Egyptian edition 
Taken by itself, this Qur ānic passage seems to be establishing a causal connection between two logically related statements: because the polytheists are ritually 'dirty' and therefore ritually 'contagious', therefore the Sacred Mosque - as a preeminent locus of prayer (mușallā) which needs to maintain its ceremonial fitness ${ }^{5}$ - is out of bounds to them (as are, by extension, all other venues of Muslim worship). It is from this understanding of the words that Goldziher believes the Sunnī authorities sooner or later distanced themselves.

But there are other ways of interpreting Qur ān 9:28, and both scriptural structure and traditional exegesis make such alternative readings plausible. If we look at the context of Sürat al-tawba (to the extent that we can speak of 'context' in the Qur'ān after Richard Bell, and it seems reasonable to do so here), ${ }^{6}$ it represents a sufficiently compelling conception to say that the idolators/polytheists continually referred to in this chapter are Muhammad's immediate opponents hailing from Mecca. The introductory verses of the chapter read:

An acquittal, from God and His Messenger, unto the idolaters with whom you made covenant: 'Journey freely in the land for four months; and know that you cannot frustrate the will of God, and that God degrades the unbelievers.'

A proclamation, from God and His Messenger, unto mankind on the day of the Greater Pilgrimage [al-hajj al-akbar]: God is quit, and His Messenger, of the idolaters. So if you repent, that will be better for you; but if you turn your backs, know that you cannot frustrate the will of God....

Then, when the sacred months are drawn away, slay the idolaters wherever you find them, ...

Will you not fight a people who broke their oaths and purposed to expel the

of King Fu’ād. Arberry numbers every fifth verse and follows the division established by Gustav Fluegel.

${ }^{5}$ There are three potential 'targets' of pollution in the Muslim țahāra (purity) code: the human body (al-badan), the clothing used to cover it (al-thawb) and the venue of devotions (al-musallā). Purification water and the Qur`ānic codex may perhaps be added to this list, but the issue is complex.

${ }^{6}$ See the first chapter of Marion Holmes Katz, Body of Text (Albany: State University of New York Press, 2002). where the author outlines and implements a cautious yet persuasive approach to Qur'ān contextualization involving (inter alia) the apparent 'bunching' of relevant passages in particular scriptural locations - an approach which has partly inspired the following analysis. 
Apostle . . .?

These verses and those that follow them are a pretty clear indication that the exhortations against the untrustworthiness and evil ways of the mushrikūn are - in this particular Qur ${ }^{\circ} \bar{a}$ nic context - direct reactions to political developments in the earliest days of Islam. They are provisions 'in time', as it were. Qur'ān 9:28 itself bears witness to this immediacy and specificity, in directing the Muslims to turn the polytheists away from the Sacred Mosque 'after this year of theirs' (the year in question was $9 \mathrm{AH}$ or $631 \mathrm{CE}){ }^{8}$

More evidence that this was indeed the Qur ān's frame of reference comes from the verses directly leading up to Qur ${ }^{\circ} \bar{n}$ 9:28, which include the following:

It is not for the idolators to inhabit [tend, maintain] God's places of worship, witnessing against themselves unbelief; those - their works have failed them, and in the Fire they shall dwell forever.

Do you reckon the giving of water to pilgrims and the inhabiting [tending] of the Holy Mosque as the same as one who believes in God and the Last Day and struggles in the way of God? 9

When we encounter, only a few lines down, God's injunction that the idolators 'not come near the Holy Mosque after this year of theirs [is over]' (Qur ${ }^{\top} \bar{a}$ 9 9:28), we are certainly within our rights to assume that the same specific Meccan polytheists - the immediate enemies of Muhammad and the Muslims - are the subject. It is therefore eminently possible that the Qur ān did not intend to prohibit mushrikūn (however they are defined) from entering all mosques from that point on in history and wherever they might be located, but rather solely and contextspecifically to forbid Meccan polytheists from trespassing on the grounds of the haram and approaching the central shrine of the $\mathrm{Ka}^{\mathrm{c}} \mathrm{ba}$. Such a reading would be consistent with the eventual 'lenient' ruling of the majority of Sunnī exponents, who allowed non-Muslims access to mosques the world over, and it would not require the 'abandonment' or 'interpretation out of existence' of original scriptural intent posited by Goldziher: there was no all-encompassing prohibition to be abandoned in the first place. Thus, indeed, most Sunnī commentaries do render this

\footnotetext{
${ }^{7}$ Qur ${ }^{\circ}$ ān 9:1-5, 13; trans. Arberry.

${ }^{8}$ See Muhammad b. Jarīr al-Ṭabarī, Jāmi ${ }^{c}$ al-bayān ${ }^{c}$ an ta ${ }^{\supset}$ wìl āy al-Qur ${ }^{\supset} \bar{a} n$ (Beirut: Dār al-Fikr, 1995), 10: 136 (no. 12895).

${ }^{9}$ Qur ${ }^{\circ} a \bar{n}$ 9:17 and 19; trans. Arberry, with additions in square brackets.
} 
aspect of Qur ān 9:28, specifically distinguishing those banned from Muslim places of worship during the period in question from the 'People of the Book':

This prohibition is limited to the polytheists who were forbidden from entering Mecca and the remaining mosques [anywhere] because they did not possess the status of a Protected People (lam takun lahum dhimma) and the only choice that was offered them was Islam or the sword (kāna lā yuqbal minhum illa l-Islām awi l-sayf) - and these were the 'Arab polytheists' (al-mushrikūn al- ${ }^{c}$ arab). ${ }^{10}$

Commenting on the phrase 'let them not come near the Holy Mosque after this year of theirs,' our earliest extant exegetical work, that of Muqātil b. Sulaymān (d. $767 \mathrm{CE}$ ), says simply that 'this refers to the Arab polytheists' (yac ni mushriki l- ${ }^{c}$ arab). ${ }^{11}$ The renowned exegete Ibn Kathīr glosses the same clause with the words: 'This constitutes a denial of access to [all those] excepting [pagan] slaves and members of the Protected Peoples (illā an yakūna 'abdan aw ahadan min ahli $l$ dhimma), and he cites an injunction of the Prophet: 'A polytheist shall not enter our mosques after this our year, save only the People of the Covenant and their servants (ahl al- ${ }^{c}$ ahd wa-khadamuhum).' 12

Fakhr al-Dīn al-Rāzī also supports the claim that only Meccan mushrikūn are referred to in Qur ${ }^{\circ} \bar{a}$ 9:28, albeit in an indirect fashion. He argues that the masjid al-harām whence the unbelievers were thenceforward to be banished comprises not just the place of worship itself (nafs al-masjid) but the sanctuary zone in its entirety (jam $\bar{\imath}^{c}$ al-haram):

The proof of this may be found [in the continuation of the verse]: 'If you fear poverty, God shall surely enrich you of His bounty, if He will;;.' [This refers, as al-Tabari and others tell us, to the complaint of many Muslims upon learning of the new ban: 'Whence now shall come our sustenance? The polytheists are no longer permitted (to enter) and thus the caravans have been cut off from us (nufiya l-mushrikūna wa-nqața ${ }^{c}$ at al- ${ }^{c} \bar{i} r$ )! ${ }^{13}$ Now [continues al-Rāzī] the locus

\footnotetext{
10 Abū Bakr Aḥmad b. ${ }^{\mathrm{c}}$ Alī al-Rāzī al-Jașșāṣ, Aḥām al-Qur ān (Beirut: Dār al-Kutub al- ' Ilmiyya, 1994), 3: 114. Al-Jașșāṣ suggests another possible understanding as well, but it is not relevant to our question. On the 'Arab polytheists' see Yohanan Friedmann, 'Classification of Unbelievers in Sunn̄̄ Muslim Law and Tradition', Jerusalem Studies in Arabic and Islam 22 (1998): 163-95, esp. $168 \mathrm{ff}$.

${ }^{11}$ Muqātil b. Sulaymān, Tafsīr (Cairo: Al-Hay ${ }^{\circ} a$ al-Mișriyya al- ${ }^{\mathrm{c}}$ Āmma li-1Kitāb, 1984), 2: 165.

12 ' Imād al-Dīn Ismāc̄ill b. ' Umar b. Kathīr, Tafsīr Ibn Kathīr (Cairo: alMaktaba al-Tawfiqqiyya, n.d.), 4: 90.

13 Țabarī, 10: 137 (nos. 12896-97 and ff.).
} 
of trading was not within the Mosque itself [but rather in its environs, the campus of the haram], and if this verse intended to prohibit polytheists only from entering the Mosque proper, what would be the basis for fearing poverty? They could only have feared poverty if the polytheists were being banned [by this revelation] from the marketplaces and seasonal fairs [which were outside of the actual venue of worship] (innamā yakhāfün al- ${ }^{c} \bar{l} l a$ idha munic $^{c} \bar{u}$ min hudūiri l-aswāq wa-l-mawāsim). Further evidence for this may be garnered from God's words [elsewhere in the Qurª̄n]: 'Glory be to Him, who carried His servant by night from the Holy Mosque [al-masjid al-harām] to the Further Mosque, ... ${ }^{14}$ coupled with the unanimous opinion of the authorities that the Messenger, upon whom be blessings and peace, was lifted up on that occasion from the abode of Umm Hānī [which was located inside the haram but outside the place of prayer. Thus, just as in the verse just cited, Qur ${ }^{3} \bar{n}$ 17:1, the term al-masjid al-harām indicates the entire sanctuary zone, so in our verse, Qur ān 9:28, the polytheists are being banned from the entire sanctuary zone]. ${ }^{15}$

What al-Rāzi has done is give us even more reason to confine the reference, and perhaps even the application, of the divine injunction in Qur ${ }^{\circ}$ an 9:28 to the immediate political situation in the last years of the Prophet's life. The inclusion of the market-places and other extraspiritual areas in the ban militates for a focus not on the ceremonial danger presented to the masjid al-harām, the mușallā par excellence, by the polluted persons of non-Muslims, but on the abolition - hard on the heels of the Muslim conquest of Mecca - of the traditional, pre-Islamic structure of ceremonial administration and commerce in favor of a new order.

Be that as it may, we have seen above the direct testimony of more than one Sunni exegete to the effect that the second clause of Qur ān 9:28 - 'so let them not come near the Holy Mosque after this year of theirs [is over]' - had in mind Arabian idolators, not Jews or Christians ('This prohibition is limited to the polytheists, who were forbidden from entering Mecca and the remaining mosques because they did not possess the status of a Protected People.' $)^{16}$

Now things become difficult, because at the same time that the Sunni commentators and legists distinguish between the Meccan polytheists and the monotheist scriptuaries in the context of the second clause of Qur ān 9:28, they mostly opt for the identity of these two groupings in

\footnotetext{
${ }^{14}$ Qur`ān 17:1; trans. Arberry.

15 Fakhr al-Dīn Muhammad b. ${ }^{~}$ Umar al-Rāzī al-Shāfícīi, Mafātīh al-ghayb (Cairo: al-Maktaba al-Tawfīqiyya, n.d.), 16: 23.

16 Al-Jașșāṣ, cited above, p. 5.
} 
the context of the first clause of the verse: 'O believers, the idolaters are indeed unclean.' 17 We would know this even without the direct attestation to this effect of the jurists and exegetes: because a debate raged regarding the various legal implications of this first clause for centuries after Arabian polytheism had disappeared. For the phrase innamā l-mushrikūna najas to harbor anything more than historical import, it would have to be perceived as subsuming all unbelievers ( $k$ uffär) under its rubric - and it is, in fact, thus perceived. Moreover, just as evidence for the differentiation between Arab polytheists and the dhimmīs can be culled from certain passages in Sürat al-tawba, so the lumping together by most Sunnī jurists of Peoples of the Book with the idolatrous pagans under the umbrella designation mushrikūn in the first clause also finds independent support in the context of our chapter. The verses immediately following upon 9:28 are most revealing in this connection:

Fight against such of those who have been given the Scripture as believe not in Allah nor the Last Day, and forbid not that which Allah hath forbidden by his messenger [that which Allah and His messenger have forbidden] (wa-lā yuharrimūna mā harrama llāhu wa-rasūluhu). .. . The Jews say: Ezra is the son of Allah, and the Christians say: The Messiah [Jesus] is the son of Allah. That is their saying with their mouths. They imitate the saying of those who disbelieved of old (yud̄āhi ${ }^{\supset} \bar{n}$ a qawla lladhina kafarū min qablu). Allah (Himself) fighteth against them [May God fight against them!]. How perverse are they! They have taken as lords besides Allah their rabbis and their monks and the Messiah son of Mary, when they were bidden to worship only One God. There is no God save Him. Be He glorified from all that they ascribe as partner (unto Him)! . . . He it is Who has sent His messenger with the guidance and the Religion of Truth, that He may cause it to prevail over all religion, however much the disbelievers are averse (wa-law kariha l-mushrikūna). ${ }^{18}$

The interchangeability manifest in these verses approaches full identity, and the comparison of qualities between scriptuaries and pagans is quite blatant. It is thus not difficult to find even a Qur ānic basis for the association of the ahl al-kitäb with the polytheists, at least for certain

17 This has been shown decisively in Maghen, 'Strangers and Brothers', $201 \mathrm{ff}$. Different demographic mappings of the non-Muslim world are employed for different legal purposes in the Shari ${ }^{\mathrm{c}} \mathrm{a}$, and in the case of the purity of persons, ahl al-kitāb are subsumed under the rubric of mushrikūn.

${ }^{18}$ Qurº̄n 9:29-31, 33; trans. Pickthall, with additions or alterations in square brackets. 
purposes. ${ }^{19}$

The Sunnī understanding of the various components of Qur ${ }^{\top} \bar{a} n$ 9:28 as well as the plain sense of the verse itself in scriptural context - would therefore appear to involve a difficult bifurcation. The first clause (innamā l-mushrikūna najas) is perceived as including the ahl al-kitāb, whereas the second (fa-lā yaqrabu l-masjida l-harāma bac $d a{ }^{c} \bar{a} m i h i m$ $h \bar{a} d h \bar{a})$ is seen as excluding them. Although the conjunction $f a$ connecting the first clause to the second is naturally seen as denoting tafarru $^{c}$ (deduction), in terms of its traditional Sunni interpretation the second clause is neither a consequence nor a confirmation of what precedes it in the verse. A disjunction was early on created between these two phrases, even though they are juxtaposed back-to-back and syntactically and logically connected. As strange and antagonistic to the plain meaning of the text as this may appear, the traditional Sunni exegesis of Qur ān 9:28 does not really understand this verse to be saying that because the mushrikūn are impure, therefore they must be barred from the main and other mosques. After all, the first clause - 'the

${ }^{19}$ On the other hand, the express scriptural prohibition against marrying the daughters of idolators - wa-lā tankih ū l-mushrikāt (Qur ān 2:221), when coupled with the explicit permission granted to marry the daughters of Jews and Christians: hillun lakum . . . al-muhsanātu mina l-mu’mināti wa-l-muhsanātu mina lladhīna ütū l-kitāba min qablikum ("permitted to you . . . are the chaste believing women and the chaste women from among those who received the Book before you' [Qurª̄n 5:5; trans. mine]) - causes problems for such a comparison (questions of naskh or abrogation of certain verses by others cannot be taken up in the context of an analysis of this sort). Muslim scripture and tradition follows different definitions and classifications of people depending on the situation. Some offer Qur ān 9:30 in explanation of this seeming paradox: 'And the Jews say: Ezra is the son of Allah, and the Christians say: The Messiah is the son of Allah.' The implication is that the members of these religions worship the parent-child celestial diumvirate and are therefore not true monotheists. Others point to the fact that the Qur ān regularly hedges its descriptions of Jews and Christians, and does not perceive either group monolithically: it regularly accuses (for instance) 'a group among you [Israelites] (farīqan minkum)' - i.e., not all of you - of treason or recalcitrance, and does not neglect, after excoriating the Jews for 'turning your backs [on God]', to add the qualification: 'except for a few of you' (Qur ${ }^{5} a \bar{n}$ 2:83). Even the opening of the passage we have just cited in the text - 'Fight against such of those who have been given the Scripture as believe not in Allah nor the Last Day' - could be read as excluding from the hostilities those scriptuaries who do believe in God and the Last Day (and not, e.g., in the Trinity or in Ezra as the son of God), although the continuation of the verse is less ecumenical. 
idolaters are indeed unclean' - is considered to include Jews and Christians (as we said), and to indicate that they are indubitably najas; and yet they are explicitly exempted by the Sunnī mufassirūn (as we saw) from the ban from sacred space enjoined in the following clause (and no doubt as a consequence allowed into most if not all mosques by three out of the four Sunnī madhāhib [as we saw at the outset of this paper]). The syllogism is clear: if being 'unclean' in the sense described in the first clause of Qur'ān 9:28 is not grounds for exclusion from a mosque (even, according to the early exegetes and the Hanafiyya, from the Sacred Mosque), then this clause cannot follow upon (or even be relevant to) the second clause of Qur ${ }^{\circ} \bar{a}$ 9:28, the whole purport of which is the institution of that very exclusion. Against all grammatical and syntactical instincts, then, the tradition (especially the legal tradition) has employed each part of this verse for a different purpose.

It is interesting to note in this connection what al-Ṭabarī tells us about ${ }^{\mathrm{c}}$ Umar b. ${ }^{\mathrm{c}} \mathrm{Abd}$ al- ${ }^{\mathrm{c}} \mathrm{Azi} \mathrm{z}$. This zealous caliph, famous like his predecessor of the same name for his strict application of measures regarding the ahl $a l-k i t a \bar{b}$, at one point commanded in a rescript: 'Prevent the Jews and Christians from entering the mosques of the Muslims!' basing his prohibition on the statement of God: 'The idolators are indeed unclean. ${ }^{20} \mathrm{We}$ learn much from this anecdote that supports our analysis of the early exegetical perception of Qur ${ }^{\curvearrowright} \bar{a} n$ 9:28. Note that the caliph did not seek support in the second clause of the verse, 'So let them not draw near the Holy Mosque after this year of theirs [is over],' even though this was the clause that directly addressed his issue: mosque access. He could not make use of it, we would argue, because it had long been understood as referring solely to the Arabian polytheists of Muhammad's time and excepting dhimmis. He was left with the first clause, and attempted to hang his legislation on that: polytheists - a term that he knew was seen by the exegetical and legal tradition as including Jews and Christians are impure, and mosques are to be protected from ritual defilement. Ergo: No People of the Book may be allowed into Muslim mosques. ${ }^{21}$

20 Ṭabarī, 10: 136 (no. 12893): ${ }^{c}$ Umar b. ${ }^{c} A b d$ al- ${ }^{c}$ Azìz kataba: imna ${ }^{c} \bar{u} l-$ yahūda wa-l-nașāra min dukhūli masājidi l-muslimīn, wa-ttabaca fi nahyihi qawla llāh: 'Innamā l-mushrikūna najas.'

${ }^{21}$ A brief survey of the principles informing the Islamic system of ritual purity (tahāra) will facilitate a better understanding of what follows. According to that system, Muslims can become ceremonially 'polluted' or 'precluded' in two primary ways: (1) by coming into, and remaining in, contact with a set of substances or organisms possessing a status known (by relatively late authori- 
ties) as najāsa hissiya/haqīqiya or 'tangible impurity', for example: urine, feces, blood, semen, pigs, dogs, carrion, wine, pre-ejaculatory fluid, a 'marred' egg (containing a blood-spot); and (2) by experiencing certain occurrences or committing certain acts, including (a) those designated as 'minor events' (al-ahdāth $a l$-șughrā, sing. hadath) such as urination, defecation, bleeding, regurgitation, ejaculation of 'pre-ejaculatory fluid' (madhī) or 'prostatic fluid' (wadhī/wadī), flatulence, laughing, sleeping, fainting, touching the genitals, palpating women, ingesting camel flesh; and (b) those designated as 'major events' (al-ahdāth al$k u b r a \bar{a}$ ), consisting of menstruation, sexual intercourse, ejaculation of actual semen $(\operatorname{man} \bar{l})$ and lochia or puerperium (nifās). In contradistinction to the 'tangibly' contaminating substances enumerated above in clause (1), these latter acts or occurrences are classed together (again, only by comparatively late authorities) under the rubric of najāsa ma nawiya/hukmiya, meaning something like 'abstract impurity'. They are also known as nawāqid (sing. nāqid) al-wudu $\bar{u}^{\supset}$ or nawāqid al-ghusl, minor or major violators of ritual fitness. Many of these items are subject to juristic disputes. Some, like the pollutive capacity of laughter and of consuming camel meat, have been effectively dismissed.

In all cases of ritual 'pollution', whether due to 'tangible' or 'abstract' impurity, a situation has arisen for the Muslim believer which precludes prayer and certain other obligatory or meritorious activities (however, unlike the case in most, if not all, other purity systems the world over, this 'contaminated' individual cannot transmit his impurity onward to other persons, places or things). If a Muslim - or his clothing or place of prayer (mușalla $)$ - encounters impure matter (najāsa hissiya), that matter and its residue should be neutralized through various types of directed cleansings and sprinklings, subsumed under the heading izālat al-najāsa (removal of impure entities). In order to exit the comparatively more serious predicament incurred as a result of a 'minor event' (clause 2.a above), an alleviation of the state of ceremonial uncleanness ( $\mathrm{raf}^{\mathrm{c}} \mathrm{al}$-hadath) must be effected through the stylized series of ablutions known as $w u d \bar{u}^{2}$. 'Major events' (clause 2.b above) induce the more consequential defilement of janāba or 'distancing', and must be dealt with by means of the full body washing called ghusl. In either case - of wudū ${ }^{\jmath}$ or ghusl - if water is not found, clean earth or sand may be substituted (tayammum). Until the given ritual 'problem' contact with najāsa, occurrence of a hadath, or incurrence of janāba - is solved via the appropriate type of lustration, the believer's prayers will be invalid (la șalāta li-man lā wuḍ̂̀̃ a lahu [Abū Dāwūd, Sunan Abī Dāwūd, "Bāb al-tasmiya "alā al-wựū̄”", hadīth no. 101 (Cairo: al-Dār al-Mișrīyya al-Lubnāniyya, 1408/ 1988), 1: 25, and numerous places elsewhere]). Depending on the level of contamination, s/he may also be prohibited from engaging in other religiously significant acts (entering a mosque, fasting during Ramaḍān, performing the pilgrimage, handling - perhaps even reciting - the Qur $\left.{ }^{r} \bar{a} n\right)$. A Muslim who has yet to counteract the ritual influence of a hadath via wud $\bar{u}^{\jmath}$ is referred to as a muhdith, whereas one who has so counteracted it is known as a mutawaddi $i^{\circ}$ (or 
Why did the Sunnī fuqah $\bar{a}^{\text {o }}$ not follow the lead of ${ }^{\mathrm{c}}$ Umar b. ${ }^{\mathrm{c}} \mathrm{Abd}$ al-

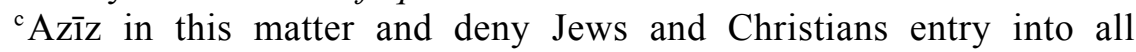
mosques? Because while they did indeed believe, with the caliph, that the phrase innamā l-mushrikūna najas included scriptuaries, they disagreed with his apparent position on the meaning of the word najas in this context. 'Umar, as we said, seems to have sought support for his (new?) prohibition in the framework of the formal Muslim tahära code, according to which the musalla is one of those objects 'vulnerable' or 'susceptible' to ritual defilement, and thus must be preserved from contact with defiling objects ( $a^{c} y \bar{a} n$ al-najāsa). ${ }^{22}$ But Sunnī exegetes and jurists never conceived of the first clause of Qur ān 9:28 that way, and almost across the board denied that it was meant to be taken in a literal, legal sense. In their eyes the najāsa of non-Muslims - whether polytheists or monotheists ${ }^{23}$ - is spiritual/symbolic, not tangible/cultic: it is an expression of 'the filth of their souls and the wickedness of their beliefs

as țāhir), or is said to be ${ }^{c} a l \bar{a} w u d \bar{u}^{2}$. One who has had sexual relations or been involved in any other 'major event' and has not yet performed ghusl is called a junub (from janāba); after executing a proper ghusl s/he is țāhir. A menstruant ( $h \bar{a}^{3} i d$ ) performs ghusl after her flow has ceased.

Secondary studies illuminating various aspects of ritual purity in Islam include: A. K. Reinhart, 'Impurity/No Danger' in History of Religions 30/1 (1990); G. H. Bousquet, 'La pureté rituelle en islam', Revue de l'histoire des religions 138 (1950): 53-71; A. J. Wensinck, 'Die Entstehung der muslimischen Reinheitsgesetzgebung', Der Islam 5 (1914); J. Burton, 'The Qur'ān and the Islamic Practice of Wudū ${ }^{\mathrm{c}}$, Bulletin of the School of Oriental and African Studies 51 (1988): 21-58; and M. H. Katz, Body of Text (Albany: State University of New York Press, 2002). Two additional articles relevant to figh al-țahära have recently appeared: R. Gauvain, 'Ritual Rewards: A Consideration of Three Recent Approaches to Sunni Purity Law', Islamic Law and Society, 12/3 (2005), and especially relevant to our present subject, J. M. Safran, 'Rules of Purity and Confessional Boundaries: Maliki Debates about the Pollution of the Christian', History of Religions 42/3 (2003).

22 See Muslim, Sahīh (= Ibn Hajar, Fath al-Bārīi), Tahāra, "Bāb wujūb ghusl albawl wa-ghayrihi min al-najāsāt idhā ḥasalat fì al-masjid" (al-Maṭba'a alMișriyya bi-1-Azhar, 1347/1929-30), 3: 191, where the Prophet is reported to have exclaimed: innā hādhihi l-masājida lā taṣluhu li-shay in min hādhā l-bawl wa-lā l-qadhar, innamā hiya li-dhikri llāhi 'azza wa-jall wa-l-șalāti wa-qirāa ati l-Qur'ān ('These venues of worship cannot abide any amount of such urine or filth, for they are places in which God's name is invoked and places of prayer and recitation of the Qur'ān').

${ }^{23}$ To the extent that one can talk, from an Islamic point of view, about a nonMuslim monotheist - the issue is far from clear. 
(khabth bätinihim wa-sü ${ }^{\jmath} i^{c}$ tiqādihim)', not of the kind of actual bodily contamination that could threaten the ritual fitness of a mosque. ${ }^{24}$

Let us come at this question from another angle and expand on the answer we have just provided: how can kuffār enter mosques according to the prevailing Sunnite opinion, given that these edifices are to be preserved from impurity, and those unbelievers have indubitably been declared 'impure' by God? The Sunnī fuqah $\bar{a}^{\supset}$ and exegetes have two basic solutions to this conundrum. The first (and probably the earlier one) is that Jews and Christians are called najas in Qur ān 9:28 because they are not meticulous about avoiding all types of filth and impurity (the Jews are especially associated with the drinking of wine and the Christians with the consumption of swine, both of which are among the $a^{c} y \bar{a} n$ al-najāsa) and, that being the case, the fear is that they might enter the (ideally) pure Muslim environment of the mosque dragging 'tangible' impurity with them. ${ }^{25}$ Thus, the Qur ${ }^{\circ} \bar{a}$ is not making a statement about the essential/intrinsic ritual status of the unbeliever's person itself, but about his religio-cultural standards and general conduct. However, based upon the pervasive legal premise in tahära of "pure until proven impure', as long as Muslims have no reason to assume that the kitāb (scriptuary) or mushrik in question will track some impure substance into the mosque, there is no problem allowing him ingress. ${ }^{26}$ This general principle of granting the benefit of the doubt also underlies a ruling of al-Shāfi ${ }^{c} \overline{1}$ on non-Muslim human $s u^{3} r$ ('backwash' in a vessel after it has been drunk from):

We were told by Sufyān b. ${ }^{c}$ Uyayna from Zayd b. Aslam from his father, that ${ }^{c}$ Umar b. al-Khațāa performed ablutions using the water of a Christian woman (either 'leftover' by her after drinking, or used by her in lustrations) and with her jar. Al-Shāfi ${ }^{\overline{1}} \overline{1}$ said: There is no problem with performing ablutions with the water of a mushrik ${ }^{27}$ and with the leftover $\left(s u^{j} r\right)$ of his ablution water ${ }^{28}$ as long as one has no express knowledge of the presence of impurity (najāsa)

\footnotetext{
${ }^{24}$ Nāṣir al-Dīn Abū Sa ${ }^{c} \overline{1}{ }^{c}$ Abd Allāh b. ${ }^{c}$ Umar al-Shīrāzī al-Bayḍāwī, Tafsīr al-Baydâ̄wī (Beirut: Dār al-Kutub al-' Ilmiyya, 1988), 1: 401.

25 Țabarī, 10: 135.

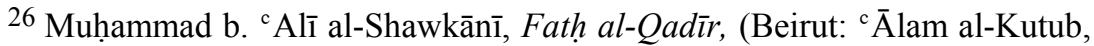
n.d.), 1: 349-50.

27 Note the identity of the Christian woman with the polytheist.

28 Meaning the water he prepared for the Muslim and then either drank from or otherwise touched before the Muslim performed ablution therewith. I read wad $\bar{u}^{\supset}$ not $w u d \bar{u}^{\supset}$ here, though the difference is slight.
} 
on/with him. ${ }^{29}$

Other instances of this type of ruling include the permission to pray in the garment of a kafir and in his house, in both cases as long as the presence of najāsa is not ascertained ( $m \bar{a}$ lam tatahaqqaq najāsatuhāa). ${ }^{30}$ Similarly, in the matter of access to sacred enclosures, the Sunni authorities give unbelievers the benefit of the doubt, and so there is no basis for excluding them from mosques based on this understanding of innama $\bar{l}-$ mushrikūna najas.

Another common suggestion offered by Sunnī exegetes and jurists in attempting to comprehend the first clause of Qur ${ }^{\circ} \bar{n}$ 9:28 is that it refers not to the habit of non-Muslims of coming into (and not breaking off) contact with what Islamic law classifies as impure substances, but rather to their habit of having sex (just like Muslims). 'The intent of these words', explains Qatāda, 'is that non-Muslims are [constantly] in a state of sexual defilement, for their full body lustration [after intercourse] is not [a proper Islamic and therefore efficacious] full body lustration (liannahu junub idh ghusluhu min al-janāba laysa bi-ghusl). ${ }^{31}$ In other words, the problem is not one of najāsa per se, but of hadath akbar, that is, not one of a permanently impure entity (whether the unbeliever himself or some substance clinging to his person), but of a temporarily defiled individual. ${ }^{32}$ This interpretation has portentous implications for

29 The fihi here could also refer to the water, but the issue is the same. Muhạmmad b. Idrīs al-Shāfí ${ }^{c} \overline{1}$, Kitāb al-umm (Beirut: Dār al-Fikr, n.d), 1: 21.

${ }^{30}$ Ibn Hajar al- ${ }^{\mathrm{c}}$ Asqalānī, Fatḥ al-Bārī bi-sharh Șaḥ̄ḥ al-Bukhārī on Kitāb al-Ṣalāt, "Bāb al-șalāt fī al-jubba al-shāmiyya" (Cairo: Maktabat al-Qāhira, 1978), 3: 22. Mālik dissents: Șaḥnūn, al-Mudawwana al-kubrā (Beirut: Dār alKutub al-' ${ }^{\mathrm{I}}$ Imiyya, 1994), 1: 140.

${ }^{31}$ Abū c Abd Allāh Muḥammad b. Aḥmad b. Abī Bakr al-Anșārī al-Qurțubī, al-Jāmic li-ahkām al-Qurª̄n (Cairo: al-Maktaba al-Tawfiqiyya, n.d.), 8: 88-89.

32 See above, n. 20, and Z. Maghen, 'Close Encounters: Some Preliminary Observations on the Transmission of Impurity in Early Sunni Jurisprudence' in Islamic Law and Society, 6/3 (1999): 348-92. In the early hadith and jurisprudence surrounding tahâra, systematic categories were not yet fully consolidated and there is often a blurring of lines between the 'tangible', intrinsic impurity in certain creatures and substances, and the 'abstract', transitory impurity affecting human beings. Thus, for instance, the possibility can be entertained in this formative phase of fiqh al-tahära that water poured over the extremities of a muhdith or junub emerges najis from such exposure (Abū al-Hasan al-Māwardī, Kitāb al-hāwwī al-kab̄̄r [Beirut: Dār al-Fikr, 1994], 1: 360-61), as if the water had come into contact with an ${ }^{c}$ ayn al-najāsa - an entity with a permanent, and 
our question, and we shall pursue it further below.

The still more widely accepted Sunnī opinion - which does not in fact contradict the previous ones - is, as we have mentioned, that the Qur ${ }^{\circ} \bar{a}$ ic usage of the term najas in Qur ān 9:28 does indeed refer to the essence of the infidel (and not to the high degree of probability that he is carrying, or has incurred, some form of impurity), but that it is at the same time entirely metaphorical and as such utterly unrelated to the formal țahāra code. Because Qur ān 9:28 represents the only occurrence of this root $-n-j-s$. - in Muslim scripture, it is hard to argue with or substantiate this notion from a critical perspective. Nevertheless, it may safely be said to sum up the overall Sunnī outlook. ${ }^{33}$ Thus, if we combine the pervasive tahära legal tendency to grant the benefit of the doubt with the knowledge that the Sunni fuqaha $\bar{a}^{\circ}$ see the 'impurity' of non-Muslims as 'spiritual' and not 'tangible', we have arrived at an understanding of why Sunnism has no problem - at least theoretically with welcoming the unbeliever into most (or all) mosques. This was not, as Goldziher describes it, a gradual evolution culminating in a thoroughgoing 'abandonment' of the original Qur'ānic and Sunnī legal outlook: it represents the earliest reading of scripture on the part of the pivotal Sunnī exegetes and the legal conclusions derived therefrom.

Junub, Ijtināb, Ajānib

To clarify the issue further, we should now step back and examine it

therefore contagiously, impure status - and not with a 'precluded' human being, who is affected by a temporary, and therefore non-transmittable, impure state. This is in contrast to rulings found even in the oldest texts to the effect that, e.g., if a menstruating woman $\left(h \bar{a}^{\circ} i d\right)$ drank from a vessel or performed ablutions with it, such water remains pure, and $w u d \bar{u}^{\supset}$ with its leftover ( $f a d l$ ) suffices to legitimize prayer (Muḥammad b. al-Ḥasan al-Shaybān̄̄, al-Aṣl [Haydarābād:

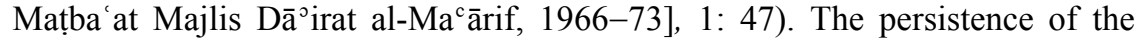
terminological inconsistency even as the substantive issues were being honed is on display in a report describing how Abū Hurayra, encountering the Prophet on one of the paths of Madina while in a state of major ritual impurity ( $w a-$ huwa junub), slinked away to immerse himself (an yaghtasila) and then returned and explained to Muhammad that he had been loathe to join him before bathing. The Prophet upbraided him: 'O Abū Hurayra, a believer never contaminates (inna l-mu’min lā yanjus).' Muslim, Șah̄ịh, Hayḍ, 'Bāb al-dalīl 'alā anna al-muslim lā yanjus" (al-Mațbaca al-Mișriyya bi-l-Azhar), 4: 66-67. As the purity code developed and its nomenclature became more exacting, such looseness and overlapping gradually disappeared, but in the earliest stages it was still possible to associate the Qur ${ }^{\circ} \bar{a}$ ic term najas with janāba.

33 See Maghen, 'Strangers and Brothers', passim. 
from the 'negative' angle. Although most Sunnī law schools allow nonMuslims into most mosques, it is also true that the majority of madhāhib (all but the Hanafiyya) are agreed on forbidding the unbeliever to enter the sacred area of Mecca surrounding the $\mathrm{Ka}^{\mathrm{c}} \mathrm{ba}$. Why are Jews, Christians and (other) polytheists not allowed to visit the haram precinct (or at least the Sacred Mosque itself)? And why are we witness to a spectrum of rulings, beginning with the Mālikiyya/Ahl al-Madina, who would prevent all polytheists from entering all mosques in Mecca, continuing with the Shäfi ${ }^{c}$ iyya, who allow them access to any mosque - as long as there is some necessity involved (li-l-hajja) - except for the Sacred Mosque itself and the surrounding sanctified areas (still other Shăfic ${ }^{c}$ ite opinions permit their admittance to the latter but not the former), and ending with Abu Haniffa, who throws the doors of any mosque open to infidel visitors - even if their visit has no demonstrably beneficial purpose (min ghayr $h \bar{a} j a$ ) - including the innermost sanctum of Islam, the masjid al-harām itself?

We have seen the problems encountered by the Sunnī expositors with regard to Qur`ān 9:28 - problems to some degree created by their own exegesis: despite the conjunction $f a$ - initiating the second clause of the verse (fa-lā yaqrabu l-masjida al-harāma), it is difficult to deduce this second clause from the preponderant Sunnī understanding of the first clause (innamā l-mushrikūna najas). If non-Muslims are not intrinsically defiled (according to the Sunnī consensus and exegesis of the first clause), then why should they be barred from the holy places of Mecca (again: according to all but the Hanafites)? The unbeliever is as pure 'bodily' (tâahir al-dhāt) as any Muslim, ${ }^{34}$ and though he lacks the religiocultural standards which would guide him to lead a relatively defilementfree existence, it is nevertheless assumed that he is not harboring any najāsa on his person until the evidence indicates otherwise. Even were we to try and base the ban on the super-cautious outlook of certain Sunni jurists, who would deny non-Muslims access to mosques and to the middle of Mecca for fear that they will track impure substances into the haram, ${ }^{35}$ we are still left with a problem. We must digress at some length

\footnotetext{
34 'As for the infidel $(k \bar{a} f i r)$, the law regarding him in the matter of purity and impurity is the same as that regarding the Muslim (hukmuhu fí l-tahära wa-lnajāsa hukmu l-Muslim). This is our policy, as well as the policy of the vast majority of our illustrious predecessors (hädhā madhhabunā wa-madhhabu ljamāhīri mina l-salafi wa-l-khalaf).' Al-Nawawī, al-Minhāj fì sharh Saḥ̄h Muslim b. al-Hajjāj (Beirut/Damascus: Dār al-Khayr, 1994), 2/4: 52.

35 This is the same reason that a Muslim women who is menstruating should
} 
on this problem and try to solve it, before we can return to our original conundrum.

The problem is this: what of the junub? Why is the Muslim believer (male or female) who incurs major impurity through a sexual encounter or the ejaculation of semen denied access to all mosques? ${ }^{36}$ This ruling is derived from Qur ${ }^{\circ} \bar{a}$ n 4:43, via an impressive feat of exegesis:

Yā ayyuhā lladhīna āmanū, lā taqrabū l-șalāta wa-antum sukārā, hatțā taclamū mā taqūlūna, wa-lā junuban illā cābirì sabīl, hatțā taghtasilū....

The literal translation of this verse yields:

O ye who believe! Draw not near unto prayer when ye are drunken, till ye know that which ye utter, nor when ye are [sexually] polluted (junuban), save when journeying upon the road, till you have bathed [immersed yourselves]. ${ }^{37}$

The context of the verse - the remainder speaks of using sand instead of water to wash oneself if sick or on a journey ( ${ }^{c}$ ala safar) - as well as that of other passages which grant special dispensations for travelers, ${ }^{38}$ coupled with the phrase illa ${ }^{c} \bar{a} b i r \bar{l}$ sabil demands that this latter phrase be rendered 'except for those journeying on the road' ${ }^{39}$ Many mufassirūn (scriptural exegetes) do in fact interpret it thus, employing this clause as

not enter a mosque, and is directed to 'stop up her vulva with a cloth' (Muwatța', Hajj [Cairo: 'Īsā al-Bābī al-Ḥalabī, n.d.], 1: 371, hadìth no. 124) before performing the circumambulation (lest she 'drip' 'ayn al-najāsa, i.e., menstrual blood, onto the hallowed terrain). Mālik rules elsewhere that if she is already inside the mosque and engaged in prayer, and she discovers her menstruation, she must immediately leave (Șaḥnūn, Mudawwana [Dār al-Kutub al'Ilmiyya], 1: 151). The immediate question that arises, and which we shall attempt to address in what follows, is this: if we have to do with a problem of 'tangible' contamination, why should there be a difference between 'regular' mosques and Meccan mosques or the sanctuary enclosure in this matter?

36 The legal argumentation is rather involved and opinions do differ, some fuqah $\bar{a}^{\supset}$ (especially Ibn Hanbal - in another display of his leaning toward leniency in purity matters) allowing a junub who has even performed $w u d \bar{u}^{\jmath}$ to remain in the mosque. This indulgence does not apply to the $h \bar{a}^{\supset} i d$ (menstruant), who poses a risk of 'spillage'. See Abū Ja ${ }^{\mathrm{c}}$ far Muḥammad b. Ya ${ }^{\mathrm{o} q u ̄ b} \mathrm{~b}$. Ishāq, al-Ușūl min al-Kāfĭ (Beirut: Dār al-Ta ${ }^{\mathrm{c}} \mathrm{rīf}, 1401$ ), 1: 50-51.

37 Trans. Pickthall; my interpolations, alternatives in square brackets.

${ }^{38}$ See Qur ${ }^{\circ} a ̄ n$ 5:5, 2:184, 2:283.

${ }^{39}$ And in this sense is it translated by Pickthall, Dawood, Arberry and others. In Hebrew, ovray derakhim, which employs the corresponding Semitic verb, is Rabbinic for those on a journey, taking the highway. 
one basis for permitting tayammum even to a junub (that is, abstersion via sand-patting also in place of ghusl, not just in place of $w u d \bar{u}^{\supset}$ ) on the condition that he is traveling. Al-Shäfi ${ }^{c} \overline{1}$, on the other hand, would read the scriptural passage in question this way:

O ye who believe! Draw not near unto prayer when ye are drunken, till ye know that which ye utter, nor when ye are polluted - except in order to pass through (illa ${ }^{c} \bar{a} b i r \bar{l}$ sabìl $)$ - till you have bathed [immersed yourselves].

Here is his comment:

The meaning of this verse is: draw not near unto the site of prayer (mawdi $i^{c} a l$ salāt), because there is obviously no concept of passing through prayer, only of passing through the site of prayer, meaning the mosque. ${ }^{40}$

Al-Shāfi ${ }^{\overline{1}}$ has thus managed to turn this verse from a statement about the rights of sexually impure Muslims vis-à-vis purification procedures scil., that if they are wayfarers, they may use sand when water is scarce to a statement about the rights of sexually impure people vis-vis mosque ingress - scil., that they may enter mosques only as a way to get somewhere, if all other routes are closed off.

Al-Tabarī is able to adduce a hadìth in the context of 'the circum-

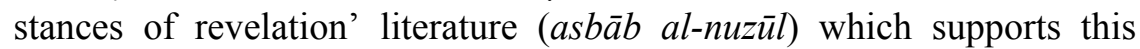
interpretation:

. . . from Yazīd b. Habīb, that there were men from amongst the Anșār (the 'host' Muslims of Yathrib/Madīna) the doors to whose homes faced the mosque (i.e., with no open space intervening), and occasionally they were in a state of janāba and could find no water [in their homes], and there was no way to get water [from the well outside, with which to perform ghusl] except by walking through the mosque. That is when God, may He be exalted, sent down [the revelation]: ' $\ldots$. nor when you are polluted - except in order to pass through' ${ }^{41}$

Why is there a need to seek a (forced) scriptural basis specifically for the prevention of the junub from entering the mosque (except to pass through), when the same prohibition for a $h \bar{a}^{\supset} i d$ or menstruant (and a $n a f s \bar{a}^{>}$- a women experiencing post-partum bleeding) seems not to require such Qur ${ }^{\top} \bar{a}$ nic grounding? It is possible that since menstruation is closely connected in fiqh discussions with janāba, that the verse covering the one form of 'preclusion' is assumed to cover the other as well. It

40 Umm, 1: 70-71. Al-Shafič̄’’s erstwhile master also evidently understood this Qurª̄nic passage thus. See Sạ̣nūn, al-Mudawwana al-kubrā (Beirut: Dār Ṣādir, n.d.), 2: 315, "Fī murūr al-junub fī al-masjid".

41 See Tabarī to 4: 43. 
is also possible that there was no verse found which conveyed such a prohibition regarding the $h \bar{a}^{\jmath} i d$, or which could be similarly manipulated to do so.

I would like to suggest another option. We began this sub-discussion by asking why the Sharī a bans the junub from the mosque. While the $h \bar{a}^{\supset} i d$ might drip menstrual blood onto the floor (as the $n a f_{s} \bar{a}^{\supset}$ might do the same with post-partum blood), it would be hard to argue that the junub poses a similar hazard: semen dries quickly, not to mention that most of the fuqah $\bar{a}^{\supset}$ rule, following a report of ${ }^{c} \overline{\mathrm{A}}^{\supset}$ isha, that janāba is contracted by julüs bayna shucabihā al-arbaca ('sitting between her [a woman's] four parts', i.e., her legs and vaginal labia or her arms and legs) and mass al-khitān al-khitān ('the meeting of the two circumcisions'), regardless of whether semen is emitted or not. ${ }^{42}$ It must also be noted, in this connection, that the Shäfic iyya do not consider semen to be najis at all (even though its emission still leads to a state of janāba in their view). With this data in mind, we cannot with confidence attribute the prohibition against a junub entering a mosque to the fear of contamination of the place of prayer via contact with ${ }^{c}$ ayn al-najāsa.

We also know that the junub cannot pollute via contact with his/her person. On top of Muhammad's scolding the junub Abū Hurayra, who was afraid to encounter the Prophet before bathing (inna l-mu'min la yanjus), ${ }^{43}$ and Mālik's permission to engage in marital relations with one's Christian junub spouse, ${ }^{44}$ al-Tirmidhī and Ibn-Māja record a tradition in which ${ }^{\mathrm{c}} \overline{\mathrm{A}}^{\mathrm{o}}$ isha recollects that she and the Apostle used to have sexual intercourse, after which her husband would perform ghusl. Then Muhammad 'would come and warm himself with me, and I would hold him tight - before I myself had performed ghusl (thumma kāna yastadf $i^{\supset}$ u bi fa-dammamtuhu ilayya wa-lam aghtasil). ${ }^{45}$ We see, then, that such temporary defilement (hadath, janāba) is not technically 'con-

42 See Nasā'i, Sunan, Tahāra, "al-Ghusl min muwārāt al-mushrik" (Cairo: Muștafā al-Bābī al-Halab̄i, 1383/1964), 1: 92; Ibn Mājah, Sunan, Tahāra, "Bāb mā jā’a fī wujūb al-ghusl min iltiqā $\bar{a}^{\supset}$ al-khitānayn" (Cairo: Dār Ihyyā' al-Turāth al- ${ }^{\mathrm{c}}$ Arabī, 1395/1975), 1: 199, hadīth no. 608.

43 See note 32.

44 Sạ̣nūn, Mudawwana (Dār Ṣādir), 2: 315.

45 Tirmidhi, Sunan, Țahāra, "Bāb [mā jāa a] fĩ al-rajul yastadfi ${ }^{\supset}$ u bi-l-imra ${ }^{\mathrm{a}}$ ba da al-ghusl" (91) (Cairo: Muștafā al-Bābī al-Ḥalab̄i, 1398/1978), 1: 210-11, hadīth no. 123; Ibn Majah, Sunan, Tahāra "Bāb fī al-junub yastadfí ${ }^{0} \mathrm{u}$ biimra ${ }^{\circ}$ atihi qabla an taghtasil” (97), 1: 192, hadìth no. 580. The Prophet's act may have been motivated by affection, or alternatively by the cold. 
tagious', that is, even if a person affected by sexual impurity were to rub him or herself against the walls of a mosque, this would in no way adversely affect the ritual fitness of that edifice. Thus, if we take the meaning of innamā l-mushrikūna najas to be, for all intents and purposes, innamā l-mushrikūna junub, then there is still no reason to ban sexually impure people from Muslim sacred space. And yet they are so banned.

Janāba must then somehow constitute a special case, a state that is contrary to the purposes of the mosque in a different fashion than other categories of impurity, a fashion which falls outside of the normal routes of 'transmission' or modes of defilement in the tahära system. This uniqueness would appear to consist in some special, intangible/spiritual quality of janāba which is conceived to be fundamentally at odds with sacred space. There is something about this particular kind of defilement which makes it, not hateful (such a notion does not work well with the overall value-neutral atmosphere of the tahära code), but 'opposed' to perhaps even in competition with - the sacrosanct character of the mosque. As I have argued elsewhere, sexual congress is seen in classical Islamic literature as the healthy mirror image of spiritual devotion, and while both are considered extremely laudible acts, they cannot co-exist in the same sphere - specifically because they both constitute powerful ecstatic activity. ${ }^{46}$ It is perhaps for this reason that, among the various categories of major ritual impurity, janāba's preclusion of residence in the mosque is singled out for scriptural reinforcement.

Now, as we shall see momentarily, when we deal with the subject of conversion, the non-believer, though considered by most of the Sunnī fuqah $\bar{a}^{\circ}$ to be pure in an intrinsic sense, is believed by them at the same time to harbor specifically the impurity of janāba (this being the justification for requiring his immersion - ghusl - upon adopting Islam). If so, then it must appear strange to us that the non-Muslim junub is permitted, according to most madhāhib, access to the mosque, whereas the Muslim junub is denied this privilege! I would suggest that what underlies this discriminatory distinction is a simple issue of probability.

The jurists realize that there is a significant difference between knowing an individual to be in a state of janāba and assuming him or her to be so. Thus, the Muslim junub is not the same as the non-Muslim

\footnotetext{
${ }^{46}$ See Z. Maghen, Virtues of the Flesh: Passion and Purity in Early Islamic Jurisprudence (Leiden: E. J. Brill, 2004), chapter 1 and passim. We know, for instance, from a number of reports that angels are said not to visit a home while the occupant is junub.
} 
junub. A Muslim, after s/he has engaged in sexual relations, is junub in an absolute sense: he has indubitably incurred the defilement of janāba (and $\mathrm{s} / \mathrm{he}$ knows it, and $\mathrm{s} / \mathrm{he}$ is expected to act accordingly). A nonMuslim is a junub by probability: the chances are that $\mathrm{s} /$ he has incurred the defilement of janāba (i.e., has had sex in the wake of which s/he did not wash properly). Since there is no way to obtain definite information on this score (short of asking - which is probably considered socially intrusive, as well as unhelpful because the unbeliever does not know the law so as to determine whether $\mathrm{s} /$ he has been contaminated or has effectively exited that state), I would suggest that the non-Muslim is essentially given the benefit of the doubt, according to the prevailing tendency of Islamic law in such matters: pure until proven impure. As in the case of minor impurity (we saw al-Shäfi ${ }^{c} \overline{1}^{\prime}$ 's ruling to the effect that 'there is no problem with performing ablution with the water of a polytheist . . . as long as one has no express knowledge of the presence of najāsa on him'), so with major impurity, the mushrik or dhimmī is considered to be in a pure state until the opposite is demonstrated, and therefore may enter a mosque, while the definitively infected Muslim may not.

Why, then, to return to our original question with which we opened this section, is the unbeliever barred specifically from the Sacred Mosque? The Qur ān cannot be the true basis for this, for as we have shown, Qur ${ }^{\top} \bar{a} n$ 9:28 is seen by most Sunnī exegetes to be referring in its ban to the Qurayshite and other Arabian polytheists of the day, not, e.g., to later history's Jews and Christians; and the status of these last is pure at any rate, according to the same exegetes' abstract, 'spiritual' interpretation of the clause innamā l-mushrikūna najas. Moreover, why, taking all the madhăhib together, is there an increasing tendency to deny nonMuslims access as we ascend the ladder from regular mosque to Meccan mosque to haram (the surrounding campus) to al-masjid al-harām (the Sacred Mosque)?

If we accept the theory that janāba is a special kind of defilement, with a uniquely problematic or antithetical relationship to the holy nature of sacred places, then we may perhaps be able to understand this phenomenon. If the issue here (in the case of janāba) is not soiling with tangible impurity in the framework of the defined and legislated tahära system (where the antagonistic or zero-sum janāba-mosque relationship makes little legal sense, and where the harām does not truly possess a distinct status), but rather a more ethereal/esoteric, less quantifiable framework of 'holiness' and that which holiness cannot abide - if this is so, then we can certainly envision a gradation of holiness along the 
ladder described above, with the neighborhood mosque at the low end and the Meccan sanctuary at the top. It makes sense, then, to distinguish: as far as the local mosque is concerned, the unbeliever can be given the benefit of the doubt regarding his/her janāba state; when it comes to the holiest place in Islam, however, it is best to err on the side of caution.

Though the above sketch is admittedly speculative, what cannot be denied is that according to the Sunni jurists the non-Muslim is forbidden entry to the sacred space of Islam (mosque or sanctuary) not because $\mathrm{s} / \mathrm{he}$ is intrinsically impure (najis al-dhatt), but because s/he has quite probably incurred a state of impurity, specifically, that of janāba. ${ }^{47}$

\section{The Judaic Regulations}

In order further to clarify the Sunnī Muslim position on the ritual status of the infidel and what underlies his right (or lack thereof) to enter mosques, it will be helpful to contrast this position with several aspects of the Jewish view of overall human - and specifically Gentile impurity, and how this Jewish view impacts on the access of 'outsiders' to sacred space. However, because according to most opinions in the Talmud the non-Jew (polytheist or otherwise) is in fact considered essentially impure - and in a 'tangible', not 'spiritual' manner (to state our conclusions from the outset) ${ }^{48}$ - and because human impurity (Gentile or Jewish, 'intrinsic' or temporary) is extremely transmittable in Jewish law - in both cases, as we have seen, in diametric contradistinction to Islamic law - for these reasons the Halakhic (Jewish legal) treatment of this subject is incalculably vast, and we can only touch on a few points relevant to our analysis. Even within these sub-areas of Talmudic jurisprudence, controversies rage the elucidation of which would fill many volumes, and we will therefore have to make do with the broadest of distillations, ignoring the myriad of related issues and numerous opposing positions to adduce statements which exemplify the overall trend. This summary approach is justified because we are interested in employing the Judaic position here merely as a 'control' or backdrop against which to better comprehend the Islamic position.

The Talmud denies Gentiles ingress to a section of the Temple Mount in Jerusalem. The eighth Mishna in the first chapter of Tractate Kelim

${ }^{47}$ Whether this was the original intention in the Qur ${ }^{\circ} \bar{a} n$ is open to question. I would doubt it, and it does not matter. We are interested in the conclusions reached by the $f u q a h \bar{a}^{j}$, which in turn became premises which enabled them and their successors to reach new conclusions.

${ }^{48}$ Although this fact has little if any relevance today, since most Judaic purity laws are no longer in force. 
(vessels) states:

Inside the wall [of Jerusalem] is holier than [the area inside the walls of other cities]. . . . The Temple Mount itself is holier than [the area inside the Jerusalem wall]. . . The khayl [the first terrace within the wall of the Temple Mount] is holier than [the space immediately within the wall of the Temple Mount], since Gentiles and those afflicted with corpse defilement (temei met) cannot enter there. ${ }^{49}$

Thus, the non-Jew is barred even from the outer courts surrounding the Temple proper, a ban which is certainly reminiscent of the Islamic prohibition.

Why is the Gentile prohibited from the Temple grounds in the Halakhic system? We shall take a rapid glance at this enormous and variegated Talmudic question with the help of a related provision found in both faiths: ritual immersion for purposes of conversion. Why does a convert have to immerse in Judaism? We have seen that the rabbis of the Mishna, in the context of banning non-Jews from the Temple area, place Gentile impurity on a par with corpse defilement, the highest level of contamination in the Jewish system. ${ }^{50}$ How is this to be understood? Is the intention (analogously to the conception of the fuqah $\bar{a}^{\supset}$ regarding unbelievers and their assumed janāba) that non-Jews are not careful about contact with corpses (and do not purify themselves through immersion from the consequently incurred death impurity) and therefore are assumed to be most probably in a constant state of defilement? Is conversion-immersion called for in order to remove this major impurity?

The answer is a definitive 'no'. First, the kind of miqve (ritual pool) immersion required of a convert is incapable of negating corpse contamination (the ashes of a 'red heifer' are required for this purpose, as well as a special ceremony). More importantly: it is one of the central principles of the Jewish purity code, that Gentiles cannot contract impurity at all. The Talmud states unequivocally (Nazir 61b):

The Gentile ${ }^{51}$ is excluded [from the preceding discussion on the sacrifices brought by Nazirites] because he can incur no impurity (yatza ${ }^{c}$ oved kokhavim

\footnotetext{
${ }^{49}$ Mishnah Kelim 1:8.

50 Those defiled by a corpse are not the most problematic from the point of view of sanctuary ingress itself, however. The Mishna in question mentions a number of types that are banned even from the compound surrounding the Temple, such as (Jewish) men and women 'with a flux' (zav).

51 The terminology employed is reminiscent of that of the Qur ān in that it also essentially means polytheist or idolator: 'oved kokhavim, 'star-worshipper'.
} 
sheh- ${ }^{c}$ ayn $l o \operatorname{tum}^{\circ} a$ ). And how do we know that he can incur no impurity? Because it is written in scripture (Numbers 19:20): 'But the man who shall be impure, and shall not purify himself, that soul shall be cut off from among the congregation.' [Scripture speaks] of one who has a congregation, ${ }^{52}$ thus excluding him who does not have one (be-mi she-yesh lo kahal, yatzah mi she cayn lo kahal).

This Talmudic passage goes on to adduce a number of additional scriptural proofs, and many other examples could be brought from the literature in support of this position..$^{53}$ What the rabbis are saying here, is that the Gentile cannot incur a state of impurity via exposure to the various sources of contamination threatening the Jew outlined in the Pentateuch and elaborated by the Talmudic system. Thus, the proselyte to Judaism does not immerse himself in the miqve to remove the kind of impurity that, for instance, requires immersion for the Jewish woman who has ceased menstruating, or the Jewish man who has had a nocturnal emission, or for any other kind of Halakhic impurity. The exclusivist/nationalist character of the Jewish faith meant that the susceptibility to ritual contamination was restricted to the Israelite community (whereas the inclusivist/universalistic nature of Islam is probably reflected in the extension of such susceptibility to all human beings). 54

That the nature of the Gentile's defilement has nothing to do with the formal Jewish purity system is also evident from the circumstances of its promulgation:

It is taught: Rabbi [Judah the Prince] said: For what reason did they rule that a Gentile corpse does not contaminate through carrying? Because his (the Gentile's) impurity in life is not from the Torah, but is a Decree of the Scribes (lefi

52 Since the reference in the Torah is to the specific congregation of Israel, the non-Jew, who cannot be banished from that congregation (because he never belonged to it in the first place), is not included.

${ }^{53}$ See, for instance, Negaim 3:1, Sifre Zuta to Numbers 19:10.

${ }^{54}$ There is even a general statement to this effect, going beyond the bounds of purity law, cited by Ahmad Ibn Hanbal: 'Unbelievers are obligated by the positive law of Islam, and especially by the proscriptions (inna l-kuffāra mukhātabūna bi-furūci l-sharīca, wa-khușūșan bi-l-manāhî̀).' See the modern editor's note to Abū al-Qāsim Jār Allāh Mạ̣mūd b. ' Umar al-Zamakhsharī al-

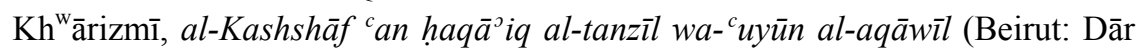
al-Kutub al- ${ }^{-}$Ilmiyya, n.d.), 2: 253. This pregnant statement, so significant for Muslim and non-Muslim relations, requires further study 


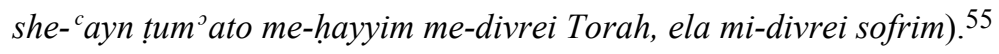

Gentile impurity was a later Rabbinic addendum, possibly for sociopolitical reasons of segregation from the surrounding peoples. The outsider was endowed with a form of defilement which - unlike any incurred contamination in the formal Jewish purity code - had no cure (except absorption into the Israelite tribe via conversion to Judaism). In a word, he was both permanently saddled with a status, and permanently denied a state, of impurity - the mirror opposite of the Islamic outlook in which, as we have seen, the infidel is not considered to possess a status, but definitely is susceptible to contracting a state, of impurity.

It is, however, extremely important to recognize the following distinction: while the Gentile impurity decreed by the rabbis may well be characterized as 'permanent', it is somewhat more problematic to describe it as 'intrinsic'. We will continue to do so, but with the following proviso in mind. After all, before the rabbis came along in the early centuries after Jesus and declared the members of the surrounding idolatrous nations ritually contaminating, the predecessors of those pagans were considered eminently pure for a good thousand years by their Israelite neighbors. Moses was no more reticent about shaking Jethro's hand than Samson was about sleeping with Delilah. Post-biblical Gentile impurity is therefore 'artificial', literally man-made, and in that sense hard to speak of as 'intrinsic' or 'inherent'.

Furthermore, it must be stressed that the rabbinical attempt to discourage the mingling of Jews with idolaters by declaring the latter tangibly defiling, while it does evince a negative attitude to their way of life and its potential influence on Jews, nevertheless does not really carry with it a stigma in itself. Decreeing something ceremonially contaminating in Judaism does not necessarily imply disparagement of that thing. Torah scrolls and books, for instance, were declared by the same Talmudic authorities to be 'defiling of hands' (metamei yadayim). Now, few objects are more venerated in the Jewish environment than these, but this decree - like that concerning the impurity of Gentiles - was enacted for a practical purpose: since, at the time, many Jews were careful about conveying ritual pollution to the food they ate, the rabbinical assignment of a polluting capacity to sacred books served to keep those books far away from the kitchen, and this separation, in turn, protected the pages of the Pentateuch and its satellite texts from mice.

Upon immersing in the context of conversion to Judaism, then, the

55 Niddah 69b. 
Gentile (symbolically) ${ }^{56}$ removes a 'bodily' - even though humanly declared - condition of defilement. ${ }^{57}$ The Talmudic ranking of Gentile impurity on the (extremely potent) level of corpse contamination is perhaps echoed in a Rabbinic statement regarding conversion, from the school of Hillel the Elder: 'He who separates from the foreskin, it is as if he separated from a grave (ha-poresh $\min$ ha- ${ }^{c}$ orla ke-poresh $\min$ haqever). ${ }^{58}$ That is, the removal of the foreskin through circumcision (a requirement of conversion for males) is tantamount to purification from the corpse defilement incurred through contact with, or proximity to, a grave. This is, of course, a metaphor: there is nothing technically impure about the foreskin (Jews, unlike Muslims in the debate over mass aldhakar, are discouraged from touching their penises solely to avoid becoming inappropriately aroused). ${ }^{59}$ The comparison here of Gentile impurity to corpse impurity, then, is just that: a comparison. The nonJew is not considered corpse impure (tame met) - as we have seen, he is not vulnerable to such contamination. His unique defilement, largely unrelated to and ungoverned by the precepts of the formal (biblically derived) Halakhic purity code, is analogous to corpse impurity, meaning (perhaps) that it is that severe. To answer the question we posed at the outset of this section, then, the non-Jew is barred from the Temple because he has been declared intrinsically impure. He is, to employ the Muslim terminology, najis al-dhāt.

We have seen that the Islamic view on this subject is completely different, and we shall expand upon it now briefly, in the context of conversion. Why do people who wish to become Muslims have to immerse themselves, or, more accurately, to perform ghusl? The issue is actually the subject of some debate amongst the fuqaha ${ }^{\supset}$, and we are forced to deal primarily with the majority opinion, giving the minority

\footnotetext{
56 I do not intend by this word that the Gentile's impurity was not 'real' - it most certainly was, and had important ritual consequences. I use the term 'symbolically' here because Gentile impurity is metamorphosed into Jewish purity via conversion-immersion in a way that has no parallel or 'logic' within the parameters of the formal Jewish purity system. It is a unique phenomenon.

57 See, for instance, Talmud Yerushalmi, Tractate Shabbat, Mishna 1, halakha 7; Tosefta Commentary to Tractate Pesakhim, chapter 7, halakha 13; Mishna Niddah, chapter 10, halakha 4.

58 Pesakhim 8:8. This statement has other implications in context which are too complex and far-reaching to enter into here.

59 Solomon Ganzfried, Kitzur Shulkhan Arukh (New York: Hebrew Publishing Company, 1961), 4: 5.
} 
positions short shrift due to lack of space. The answer is, first of all, that - according to many authorities - converts do not always have to immerse. In certain circumstances the consensus of the schools of law is that immersion is only mustahabb, 'recommended'. This is because the basis for a proselyte performing ghusl is, as we have noted, the assumption that $\mathrm{s} / \mathrm{he}$ has almost inevitably incurred a state of janāba (via sexual relations, nocturnal emission, menstruation, childbirth), and has probably not done what is necessary (i.e., ghusl) to divest him/herself of that state. ${ }^{60}$ But what if we can ascertain with relative confidence that the convert in question has in fact never contracted major ritual impurity, as in the case of a child who enters Islam before puberty (qabl ihtilämihi) or prior to the onset of menstruation? Or what of a grown man or woman who apostatizes from Islam and then immediately changes his/her mind and returns to the faith, before having much of an opportunity to contract any kind of najāsa ma nawiya ${ }^{61}$ Regarding such cases the fuqaha ${ }^{j}$ are

${ }^{60}$ See Șahnūn, Mudawwana (Dār al-Kutub al-' Ilmiyya), 1: 140. The fact that tayammum (sand-rubbing) may be substituted for ghusl in the case of conversion (as in the case of 'normal', Muslim janāba) further throws into relief the ritually 'utilitarian' (as opposed to symbolic) nature of this immersion. And see there the important statement of Ibn al-Qāsim to Sạ̣nūn: al-nașrān̄ cindī junub, fa-idha aslama wa-tayammama thumma adraka al-ma $\bar{a}^{j}$, fa- ${ }^{c}$ alayhi l-ghusl ('Christians are junub in my opinion, and if one of them converts to Islam and performs sand-rubbing [in place of a wet ghusl as part of the conversion ceremony, if water is not available] and later finds water, he must repeat his major ablutions'). The janāba spoken of here is governed by the same regulations as the major impurity of Muslims. Whereas in Judaism immersion is the principle act which effects conversion to the faith, for the Shari ${ }^{\mathrm{c}}$ a the ghusl performed prior to the recitation of the shahädatayn in front of two witnesses has no bearing on the conversion itself (if all the would-be proselyte did was perform ghusl, he would remain an unbeliever). It is a means to that recitation, as the shahäda may not be uttered by one in a state of janāba. The requirement to repeat the performance of ghusl if one later finds water (after having utilized sand during the conversion ceremony) further points up the non-ceremonial (in the sense of the conversion 'ceremony') character of this act.

${ }^{61}$ Apostates incur different obligations upon re-conversion to Islam than those becoming Muslims for the first time. While the 'sins' (including the nonfulfillment of religious requirements) of the latter are covered by Qur ${ }^{\circ} \bar{a} n$ 8:38 qul li-lladhīna kafarū in yantahū yughfar lahum mā qad salafa ('Say to the Unbelievers, if (now) they desist (from Unbelief), their past would be forgiven them' [trans. Yusuf Ali]) - the former, the apostate, is required to 'make up' all the șalät, zakāt, and the like that he missed while a murtadd. See Shăfi ${ }^{\mathrm{c}} \overline{\mathrm{i}}$, Umm, 1: 61 . 
in disagreement, but the vast majority rule that for this type of convert ghusl is only recommended. ${ }^{62}$

The questions raised above throw into relief the primary factor operating here: that the issue of immersion upon conversion is one of suspicion of temporary major ritual defilement, not one of symbolic removal of intrinsic, permanent 'infidel impurity' (najāsat al-dhāt), as is the case in conversion to Judaism. This, of course, only reinforces what we already know: ultimately, according to the Islamic legal conception, the convert immerses for the same 'prosaic' reason the Muslim does: to exit the state of janāba. ${ }^{63}$

Thus, we have here an extremely interesting and complex diametric opposition between Islam and Judaism on the issue of conversionimmersion in particular, and on the ritual status of the outsider in general. Immersion in the Halakha is for the purpose of symbolically removing an inherent impurity that adheres to the non-Jew by virtue of his being a non-Jew. Immersion in the Shari ${ }^{\mathrm{c}} \mathrm{a}$ is for the purpose of actually removing a temporary impurity that has been incurred by the nonMuslim through action (even on the part of one who was originally a Muslim!). In Jewish law, the Gentile cannot contract impurity of any kind, and yet, nevertheless, he is fundamentally impure. ${ }^{64}$ In Sunnī

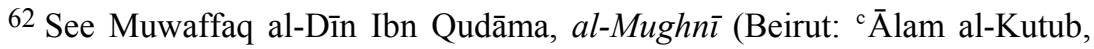
n.d.), 1: $207 \mathrm{ff}$.

${ }^{63}$ According to some rabbinic views, the Gentile is possessed of a permanent version of the normally transient defilement of the zav, that is, he with an aberrant genital flow. This should not be understood as comparable to the Islamic understanding of the matter. While the fuqaha ${ }^{\supset}$ were making the logically correct assumption that nearly all non-Muslims frequently incurred the state of janāba and had neither the knowledge nor the inclination to deliberately exit it, the rabbis were obviously not saying that every non-Jew actually, physically suffered from the specific malfunction of his reproductive organs which would render him a zav. Rather, as the renowned medieval commentator Rashi states explicitly: 'The impurity of ziva ascribed to the living Gentile is nothing but a rabbinical decree ( tum $^{\circ}$ at ziva she-alav me-khayyim 'ayna ela mi-divray sofrim)' (Rashi on Niddah 69b). For reasons which perhaps have to do with the political-social history of the Jews and their relations with their neighbors around the time of Christ, the Gentile was saddled with this permanent status of impurity, but this rabbinical enactment is clearly unrelated to the factors governing definitions of defiled persons in the formal Jewish purity code (the consequences of such a designation, in terms of the Gentile's ability to contaminate the Jew, were very real, however).

${ }^{64}$ Indeed, the Gentile is in more ways than this a kind of 'film negative' of
} 
Islamic law, the unbeliever is completely susceptible to impurity, and yet, nevertheless, he is quintessentially pure. To put it another way: in the view of the rabbis, the Gentile can never incur a state of defilement, but is at all times possessed of a status of defilement (and, consequently, is quite contaminating for Jews). In the view of the fuqaha $\bar{a}^{2}$, most nonMuslims are constantly incurring new states of defilement (just as Muslims are), but their status is pure as the driven snow.

In this same manner we have to understand the issue of corpse impurity. In both systems, Jewish and Muslim, the dead body of an outsider to the faith essentially does not contaminate (in the Halakha it does contaminate, but to a far lesser degree than a Jewish corpse; in the Shari ${ }^{\mathrm{c}} \mathrm{a}$, most opinions ${ }^{65}$ hold that it does not contaminate at all). Here again, however, the underlying motivations or principles are vastly different. The reason why a Gentile corpse does not defile in Jewish law is - like much of the Talmudic purity code - relatively inexplicable, but it unquestionably has something to do with the fact that the non-Jew cannot incur impurity and is therefore in a separate category (as well as with the fact that his 'intrinsic' defilement is the result of a rabbinical

the Jew in terms of purity law. For example, the Jew is pure, but his semen is defiling, whereas the non-Jew is a contaminant, but his semen is pure! See Mishna Miqvaot, 8: 4; Niddah 34a.

${ }^{65}$ A minority indeed holds that the dead Muslim (and käfir) does contaminate, basing itself on a hadīth of Ibn Sīrīn, who reports that a Zanjī slave fell down the well of Zamzam in Mecca and died, and Ibn ${ }^{\mathrm{c}}$ Abbās (or, in other versions, the Prophet) called for the well-water to be emptied out. Another argument advanced is that the human corpse is inedible, and, as such, should logically be impure like most inedible animals (alladhī la $y u^{\top} \mathrm{kal}$ lahmuhum (they might have just as easily claimed that the human 'died of himself' - i.e., without proper tadhkiya or ritual slaughter - and as such should be impure like all animal maytatt). One response to this claim is that the human corpse is inedible in Islamic law not as a concomitant of its impurity, but li-karamatihi, like the horse. Fuqaha $\bar{a}^{\supset}$ who opine that the cadaver is defiling, mostly Hanafi as well as Mālik himself, also generally hold that the ghusl of a dead Muslim purifies his body, but not of a dead unbeliever, because the former is commanded to pray - and thus to be pure - and the latter not (the logic is difficult to understand). As for the vast majority - who consider all dead human bodies pure - they explain that the 'ghusl' one is required to do after washing a corpse or attending a funeral is not immersion, but simply refers to a washing of the hands, no different from that of removing dirt. For these opposing view-points, see Shams al-Dīn al-Sarakhsī, al-Mabsūt (Beirut: Dār al-Ma ${ }^{c}$ rifa, 1989), 1: 82, and Ibn Qudāma, Mughnī, 1: 45 and 192. 
decree). Islam, on the other hand, considers all human beings identical in the matter of the states of impurity - and similarly immune to the status of impurity - whether Muslim or käfir, alive or dead. ${ }^{66}$ All are equal in their addamiyya. ${ }^{67}$

\section{Conclusion}

There are similarities and differences in the reasons why outsiders to the faith are barred from entering sacred areas in the Islamic and Jewish ritual-legal systems, but the underlying differences outweigh the surface similarities. Both religions deny infidels access to their most hallowed structures and spaces: Islam does so because non-Muslims obviously do not know enough about Islamic purity law to properly exit states of impurity they have contracted. One form of this impurity, janāba, is evidently possessed of a quality that makes it antithetical to the spiritual atmosphere that pervades the holy haram. Judaism bars non-Jews from the Temple campus not because of what they know (or, rather, do not know) but because of what they are: intrinsically impure by virtue of their affiliation. These differences in outlook and approach harbor significant implications for the attitude to the 'other' in each system, implications which should certainly be studied further.

\footnotetext{
${ }^{66}$ See Nawawī, Minhāj, 2/4: 52. There is, however, an interesting tradition in the 'angels do not visit...' genre - in which one of the three things which act as angel-repellent is in fact jïfat al-käfir, the cadaver of an infidel (Abū Dāwūd, Sunan, Tarajjul, 4: 78, hadìth no. 4180).

67 Ibn Qudāma, Mughnī, 1: 45.
} 